\title{
Production and reuse of waste in rural area with high density of greenhouse
}

\author{
Giovanni Russo, Giuseppe Verdiani \\ Department of Agro, Environmental Science (DISAAT), “Aldo Moro" University of Bari, Italy
}

\begin{abstract}
Agricultural activities cause the production of considerable amounts of waste sometimes dangerous that must be properly handled to avoid negative impacts on rural areas and on agroecosystems. The estimation of qualitative and quantitative characteristics of agricultural waste products and the capacity of rural land of transposing organic matter deriving from the processes of composting, is a key point for the planning and management of the waste integrated cycle. The aims of this study are the evaluation of the quantities of various types of agricultural waste on territorial scale, the amount of compost that can be used in rural areas affected by different cultures and the effectiveness of community composter in the treatment of vegetable agricultural waste for the production of green composted soil. These assessments were carried out in an area of study characterized by a high spatial density of greenhouses. The methodological procedure used is based on the use of agricultural waste production coefficients and maximum application rates of compost for cultivation. The results show the role and potential of the agricultural areas in the waste cycle from production to the potential reuse of recovered material.
\end{abstract}

\section{Introduction}

The rural areas plays a key role in the mitigation of environmental risks related to the management of urban and agricultural wastes. Besides the production of waste produced by farms, may be present in a rural area municipal or industrial wastes treatment plants that

Correspondence: Giuseppe Verdiani, Department of Agro, Environmental Science (DISAAT), "Aldo Moro" University of Bari, via Amendola 165/A 70126 Bari (Italy). Tel/Fax: +39.080 .5442960 .

E-mail: giuseppeverdiani@hotmail.it.

Key words: agricultural waste, compost, environmental sustainability

Contributions: the paper is to be attributed to the authors in equal measure. Acknowledgments: this research has been funded by the Italian Ministry of Agriculture, Food and Forestry MIPAAF, programme OIGA III, 17/10/2010 - ID 145- "SEABIA - Ecological and low impact substrates".

(C) Copyright G. Russo and G. Verdiani, 2013

Licensee PAGEPress, Italy

Journal of Agricultural Engineering 2013; XLIV(s2):e48

doi:10.4081/jae.2013.s2.e48

This article is distributed under the terms of the Creative Commons Attribution Noncommercial License (by-nc 3.0) which permits any noncommercial use, distribution, and reproduction in any medium, provided the original author(s) and source are credited. increase the environmental risk. In addition, rural areas are the final delivery for many organic wastes.

The industrial waste treatment facilities in the rural areas can cause negative impacts on the ecological balance, landscape, degree of naturalness (Pivato et al., 2012). The construction and operation of these plants is, however, necessary in order to reduce the environmental impact of the production of urban and special waste. These plants allow the recovery/recycling, volume reduction, mitigation of hazards, disposal in sanitary safety. The need to build and operate landfills, recycling and composting plants, waste to energy and waste collection centers must therefore be combined with the simultaneous target to protect the environment, the landscape, human health and quality of agricultural and livestock production. In this context is necessary mitigate the health and environmental risks determined by waste treatment plants. For the prevention and reduction of pollution caused by waste management activities, the European Directive 2008/1/EC identifies the measures to be adopted to reduce emissions to air, water and soil. According to this Directive, waste treatment plants must be built and operated by applying the "Best Available Techniques" in order to reduce the overall impact on the environment.

It 'also necessary to act on the management of waste from the stage of production, collection and transport through proper planning and organization (Calabrò, 2009).

The management of agricultural waste in rural areas is a complex problem that must, therefore, be addressed in the context of proper coordination between land use, planning and integrated cycle of wastes (Dal Sasso et al., 2009). Waste management plans are identified by Legislative Decree no. 152/06 as important tools to make sustainable waste cycle, in terms of environmental and economic possibilities. These plans should indicate the method of the collection and treatment of wastes at regional and provincial level on the basis of qualitative and quantitative characteristics.

In Italy, the evaluation of agricultural waste is uncertain because they are left in the environment, burned in an uncontrolled manner (Picuno and Scarascia Mugnozza, 1994) and transferred illegally in road bins for the collection of municipal waste. The above reasons prevent a proper evaluation of the amount of agricultural waste produced especially in rural areas characterized by the presence of small farms, this makes difficult the drafting of management plans for agricultural waste.

The agricultural waste management plans of the Abruzzo Region and the Florence Province have made a significant and concrete impulse to the proper management of national agricultural waste.

It is expected in them the selective collection of recyclable fraction of the waste (cardboard, plastic and wood, used oil, batteries and accumulators) by means of the operators of waste management services and the creation of centers of collection of separated waste in accordance with Ministerial Decree 08/04/2008 and Ministerial Decree of $13 / 05 / 2009$. These collection centers may be used for the transfer of many different types of agricultural waste for recovery/recycling. In this way are increased the "indices of recovery/recycling" of agricultural waste and emissions are reduced due to transport with the ability to 
organize and plan the itineraries of collection vehicles in the area.

The environmental impacts associated with the management of agricultural organic waste can be further reduced through their treatment and recovery on site. Are in fact available small plants (community composters, biomass heating plants, bio-gas plants) that can be installed in the farm. These plants are used to treat organic waste and to obtain compost and/or energy for use in agro-industrial processes and in particular in greenhouse sector. In fact, the compost can be used as a component of growing media of ornamental potted plants to reduce the amount of peat (De Lucia et al., 2009) and the renewable thermal energy can be used for greenhouse heating to reduce the consumption of fossil fuels (Scarascia Mugnozza et al., 2012).

The assignment of agricultural waste collection service to the municipal waste management services and the installation of on-site organic waste treatment plants, can improve the financial statements of farms, the rural landscape and the environment. These aspects have significant importance because the agricultural sector in 2008 was responsible for the production of about $440,000 \mathrm{t} \mathrm{year}^{-1}$ of waste on a national scale (ISPRA, 2011) and 9,000 t year-1 in the Puglia Region (ARPA Puglia, 2010). In Italy, in recent years, have been reduced environmental burdens connected to the waste cycle and has been improved the human/environment interaction thanks to the increase of the recovery of agricultural waste and a simultaneous reduction in the use of landfills (Atrigna et al. 2011).

A large quantity of agricultural waste consists of plastics (Scarascia Mugnozza et al., 1999) due to the increasing use of plastic films in agriculture for greenhouses covering, mulching and crop protection (Scarascia Mugnozza et al., 2007). During their use, the plastic films are subject to the reduction of mechanical strength (modulus of elasticity and elongation \% at break) and radiometric characteristics (reduction of transmissivity in PAR) due to the action of external climatic factors and therefore are periodically replaced (Picuno et al., 2009). In fact, we can estimate the production of agricultural waste plastic films consist of about 110,000 t year-1 in Italy (Dal Sasso et al., 2009 ) equal to $25 \%$ of total agricultural waste. These plastic wastes are often used in cement industries, however, their qualitative characteristics and the percentage of contaminants depend on the previous use (greenhouses, tunnels, mulching, etc.). (Briassoulis et al., 2012). The other agricultural waste, are made by: agrochemicals containers, tires and batteries of agricultural vehicles, paper/cardboard packaging, wood, iron.

At the same time, in agricultural activities can be used plastic film, produced through recycling of plastic waste (Picuno et al., 2009) and substrates products through composting of pruning and organic waste (De Lucia et al., 2009).

The composting process reproduces, under controlled conditions, the natural decomposition and humification of organic substances (Zorzi et al., 2010) by the combined action of microorganisms and chemicalphysical reactions. The correct evolution of biological and biochemical reactions that characterize the composting process is related to chemical - physical parameters such as: moisture, $\mathrm{pH}$, carbon/nitrogen ratio in the treated waste (Atrigna et al., 2011). The composting determines the mineralization of the organic substance, the production of humic acids and the production of a stable end-product defined by Italian legislation "composted soil". The composting process can be realized in industrial plants with high potential of treatment, in domestic composters and in the modern electromechanical composter plants for community with treatment capacity of about 25 waste tons year ${ }^{-1}$ (Figure 1). Community composting is a intermediate level between home composting and industrial composting and may be able to provide a treatment of organic waste physically near the production site (Accotto, 2011). The large distance of the rural areas by industrial composting facilities makes this solution economically and ecologically interesting (Silingardi, 2011) although the energy consumption is about $15 \mathrm{kWh} \mathrm{t}^{-1}$ treated.

Depending on the type of organic waste that are subjected to composting, soil improvers are classified by Legislative Decree n. 75/2010 as "Mixed composted soil improvers" (MCSI) and "Green composted soil improvers." (GCSI). The GCSI is produced exclusively from vegetable organic wastes (crop residues, agricultural residues, pruning of urban green) while the MCSI is produced from the treatment of municipal organic waste, sludge from the treatment of urban waste water and agro-industrial wastes, cuttings and prunings.

The composting of organic waste and the use of MCSI or GCSI in different agricultural sectors can help to solve two problems at the planetary level: the disposal of organic waste and the reduction of the environmental burden of agricultural process.

The use of quality compost in agriculture can make a significant improvement for agricultural food production more environmentally friendly, and allows to increase the fertility of agricultural soil, reduce erosion and irrigation requirements of the crop (Favoino and Hogg, 2002). Furthermore, the application of compost improves the biological conditions of agricultural soil by increasing the level of organic matter and humus and ensuring an adequate supply of nutrients to maintain the crops in an appropriate vegetative state with repercussions on productivity (Baldi et al., 2008).

In 2009, 3.715.302 tons of organic waste were transferred to national composting plants and 976,424 tons of soil improvements, which complies with the quality standards imposed by Legislative Decree no. 75/2010, were produced (ISPRA, 2011). The soil improvements have been used in agriculture, in open field cultivation (70\%) and in gardening and landscaping sector (30\%) (Centeremo, 2011). Landfill disposal of $3,715,302$ tons of organic waste would have resulted in the consumption of useful volumes for other waste, leachate, emission of approximately 7,200,000 tonnes of biogenic $\mathrm{CO}_{2}$. The qualitative and quantitative characteristics of the leachate and biogas produced in landfills are in fact strongly influenced by the mineralization of available organic matter and biokinetic (APAT, 2005). In landfills, the high moisture content of the organic wastes produces percolate with a high content of organic substances that together with the production of biogas results in sagging of the final cover.

The objective of this study was to determine a methodology for the evaluation of the quantity and typologies of agricultural waste and, at the same time, to quantify the amount of compost used in the agricultural sector in a particular rural area. In order to assess the role of the agricultural land in the integrated waste cycle, this methodology was applied to a rural sample area. The qualitative characteristics of an GCSI obtained from a community composter were determined using data from a greenhouse farm present in the area sample as standard. The proposed methodology allows to steer management of the collection, transport and treatment of agricultural waste to environmental sustainability.

\section{Materials and methods}

Within of the present study were evaluated potential production of agricultural waste in a rural area sample of the Puglia Region, the amount of soil improver that can be used in agriculture and the effectiveness of a community composting plant fueled by pruning .

In order to estimate the flows of waste and soil improvers used in a territory, a methodology based on the analysis of cartographic data and information relating to the production of waste was used (geographical information system - GIS). For each crop present in the analyzed area were acquired application rates of soil improver from reference data 
(Agricultural Integrated Management Regulation of the Tuscany Region, 2004).

\section{Sample area}

The sample area analyzed is the Optimal Collection Area no. 1 (ARO 1) which includes the municipalities of Bitonto, Corato, Molfetta, Terlizzi, Ruvo di Puglia (Figure 2). This geographical area has been identified according to the Puglia Regional Law no. 24/2012 for improving the waste management in compliance with the principles of differentiation, adequacy and efficiency. The area object of study is characterized by a total surface of 69,470 ha, from a suburban area with a strong agricultural vocation, by the high presence of greenhouse and the absence of widespread abandonment cultivation

\section{Community composter}

The community composter has been installed in the Municipality of Molfetta within the greenhouse farm "Primavita Srl". In order to compost organic waste coming from: the farm's pruning, horticultural residues and olive pruning produced in the study area, an automatic composter "BEETLE 50" (Comar Ecology) (Figure 3) was used. The plant consists of a cylindrical tank in insulated stainless steel, inside which there is a composting chamber characterized by a volume of 1.32 $\mathrm{m}^{3}$. The composting process is automatically controlled because turning over and the progress of the organic material is carried out by an electromechanical system with shovels. The heating of the composter is provided by $n .2$ electric heaters and is thermostatically controlled. The aeration in the composted mass is realized by a geared motor that moves the waste at time intervals ensuring optimal oxygenation and reduction of the size of the particles produced by the process. The composter is equipped with an automatic ventilation system that draws air from the outside and feeds it into the composting chamber with recirculation. The waste water resulting from the composting process is collected in a tank of 10 lt. for subsequent treatment (reuse in community composter) or for disposal. The composter has been combined with a Honda GX340 shredder to ensure adequate and uniform size of the vegetable organic material to be composted.

\section{Applied methodology}

\section{Analysis of the rural territory}

Territorial analysis of the ARO 1 was conducted using geographical information systems (GIS) with the support of the ESRI ArcMap software. The data provided by the software and analyzed were: land use, spatial distribution of crops, greenhouses, tunnels and tendone systems. Specifically, have been used the land use thematic map of the Puglia Region at 1:5000 scale according to standard European CORINE

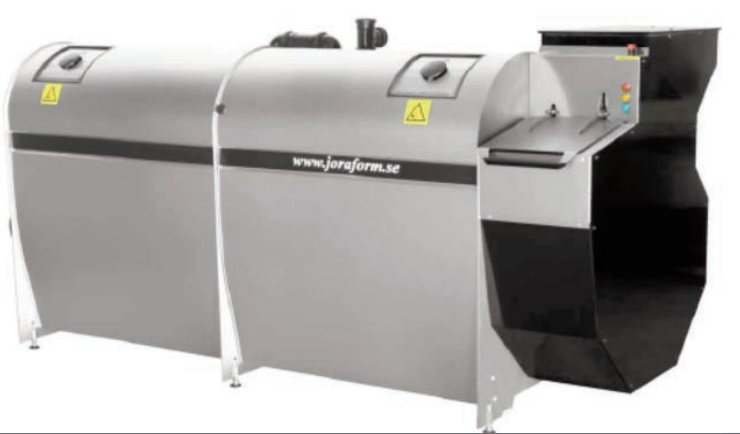

Figure 1. Community composter.

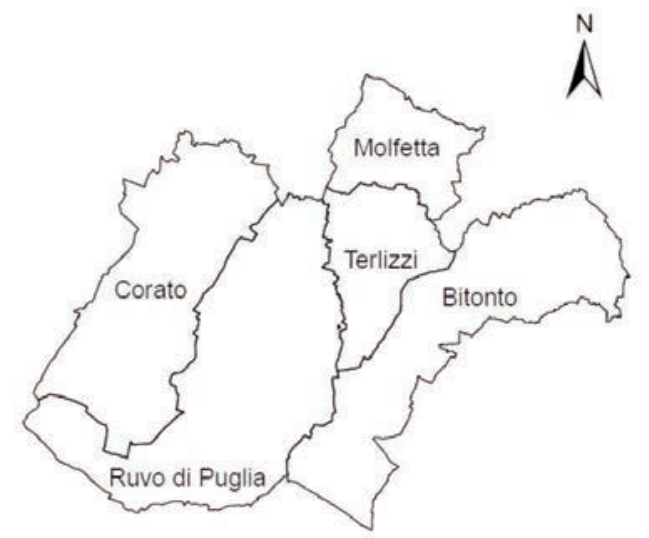

Legend

Municipal Limits

Figure 2. Municipal Limits of ARO 1.

Table 1.Coefficients of agricultural waste production.

\begin{tabular}{|c|c|c|c|c|c|}
\hline Type of waste products & $\begin{array}{l}\text { Description of } \\
\text { owaste }\end{array}$ & $\begin{array}{l}\text { Type of } \\
\text { ocultivation }\end{array}$ & $\begin{array}{l}\text { Coefficient of } \\
\text { production }\end{array}$ & $\begin{array}{l}\text { Unit of } \\
\text { measure }\end{array}$ & $\begin{array}{l}\text { Bibliographic } \\
\text { source }\end{array}$ \\
\hline \multirow[t]{4}{*}{ Plastic waste from primary production } & Plastic films for greenhouse covering & $\begin{array}{l}\text { Horticultural greenhouse } \\
\text { Vineyards covered }\end{array}$ & 1.25 & t ha $^{-1}$ year $^{-1}$ & ANPA, 2000 \\
\hline & Plastic films for mulching & Horticultural & 0.3 & $\mathrm{t} \mathrm{ha}^{-1}$ year $^{-1}$ & Cadir - Lab, 1994 \\
\hline & Irrigation pipes & Irrigation crops & 0.06 & $\mathrm{t} \mathrm{ha}^{-1}$ year $^{-1}$ & ANPA, 2000 \\
\hline & Nets storm and shade & Vineyards & 0.04 & t ha $^{-1}$ year $^{-1}$ & ANPA, 2000 \\
\hline \multirow[t]{3}{*}{ Plastic packaging } & \multirow[t]{3}{*}{ Packaging of fertilizers and soil improvers } & Arable crops & 0.0027 & t ha $^{-1}$ year $^{-1}$ & Cadir - Lab, 1994 \\
\hline & & Fruit trees & 0.0018 & t ha $^{-1}$ year -1 & Cadir - Lab, 1994 \\
\hline & & Horticultural & 0.003 & t ha $^{-1}$ year $^{-1}$ & Cadir - Lab, 1994 \\
\hline \multirow[t]{4}{*}{ Agrochemical waste } & \multirow[t]{4}{*}{ Empty agrochemicals containers } & Arable crops & 0.0005 & $\mathrm{t} \mathrm{ha}^{-1}$ year $^{-1}$ & Cadir - Lab, 1994 \\
\hline & & Vineyards and olive trees & 0.0012 & t ha $^{-1}$ year $^{-1}$ & Cadir - Lab, 1994 \\
\hline & & Fruit trees & 0.0028 & $\mathrm{t} \mathrm{ha}^{-1}$ year $^{-1}$ & Cadir - Lab, 1994 \\
\hline & & Horticultural & 0.0009 & t ha $^{-1}$ anno-1 & Cadir - Lab, 1994 \\
\hline \multirow[t]{3}{*}{ Vegetable waste from primary production } & \multirow[t]{3}{*}{ Cuttings and prunings } & Vineyards & 2.4 & t ha ${ }^{-1}$ anno $^{-1}$ & ANPA, 2000 \\
\hline & & Fruit trees & 2.75 & t ha ${ }^{-1}$ anno-1 & ANPA, 2000 \\
\hline & & Olive trees & 1.7 & t ha $^{-1}$ anno-1 & Cotana e Cavalaglio, 2008 \\
\hline
\end{tabular}


Land Cover and regional digital color orthophoto with a ground pixel resolution of $50 \mathrm{~cm}$. In order to extract information on the area: occupied by the different agricultural crops (olive groves, vineyards, orchards, crops, vegetables), covered by greenhouses and screenhouse, mulched with plastic film areas, were realized photo-interpretation and geo-processing on the cartographic bases employed.

\section{Calculation of agricultural waste production on a regional scale}

The quantitative and qualitative evaluation of the typologies of agricultural waste in the study area was carried out by applying the factors of production that combine the spatial extent of the different cultivated areas to the quantities of waste produced. The coefficients of production of agricultural waste typologies that characterize the different cultivations (Table 1) were thus extrapolated from literature sources.

Evaluation of the amount of MCSI that can be used in the agricultural areas

The evaluation of the amount of MCSI that can be used in the area was made on the basis of maximum doses of nutrients (N, P, K) that can be applied to the soil. These quantities are given in the Agricultural Integrated Management Regulation of the Tuscany Region (2004) for

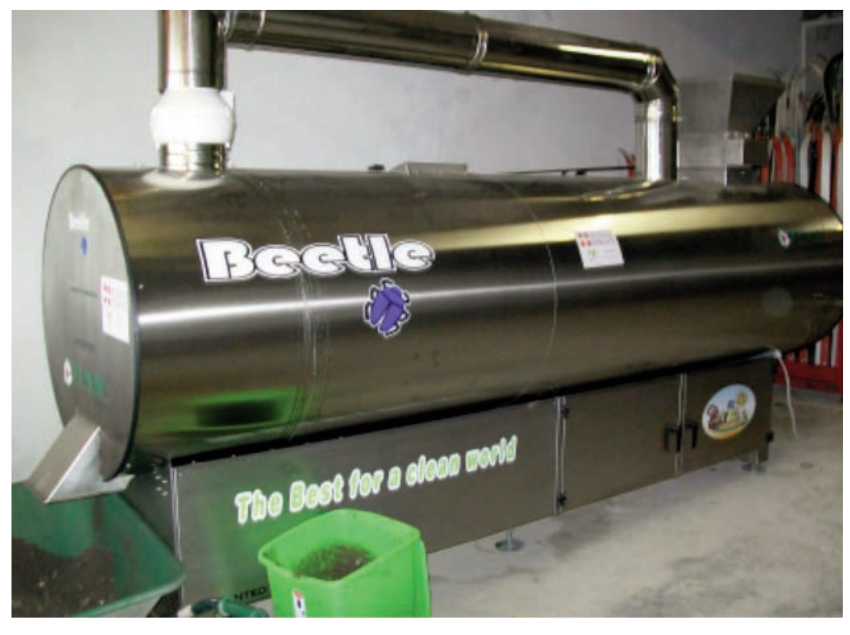

Figure 3. Beetle community composter.

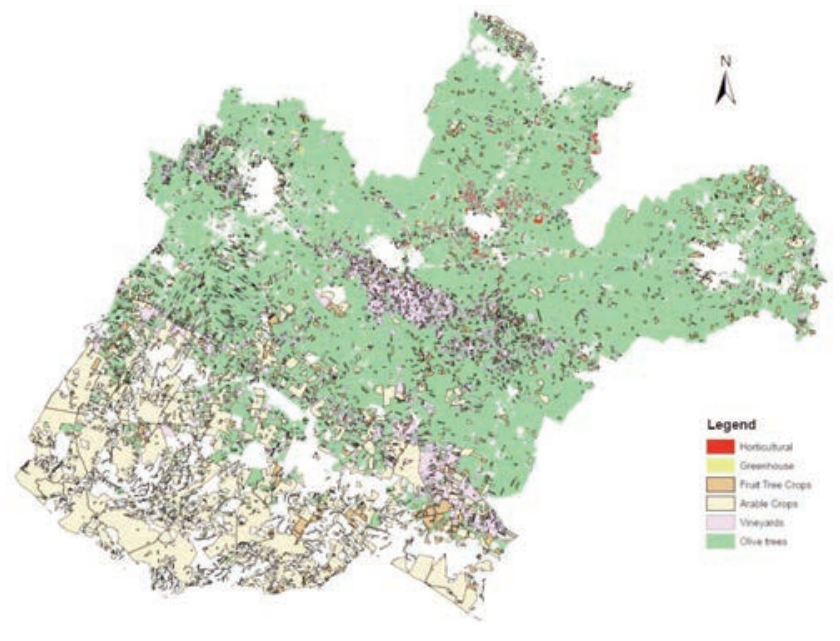

Figure 4. Land use in rural areas of ARO. each crop and take into account the expected normal fertilization. The maximum amount by weight of MCSI that can be applied annually to different crops is shown in Table 2.

These collected data have allowed to calculate the mass of organic wastes from urban and agricultural areas required for the production of MCSI that can be applied within the study area. This calculation was performed assuming the hypothesis that $1 \mathrm{~kg}$ of organic waste produces $0.3 \mathrm{~kg}$ of MCSI. It was also verified whether the amount of municipal organic waste in the ARO 1 may be entirely destined for composting and reused in the provenance rural areas.

\section{Assessment of the community composter effectiveness}

For the assessing the effectiveness of the composter are ongoing experimental composting tests by different agricultural organic matrices. Were carried out chemical - physical analysis of composted organic matrices and produced GCSI. In the composter were conferred: pruning olive trees, and horticultural and floricultural organic waste. In order to enter in the chamber of composting a mixture with particle size between $1-10 \mathrm{~cm}$, low percentage of impurity, moisture content of between $50-70 \%$ and a $\mathrm{C} / \mathrm{N}$ ratio between 20 and 30, the organic material was triturated in Honda GX340 shredder. The analysis carried out (Table 5) On organic matrices showed a reduced nitrogen content. For this reason, in the composting chamber was introduced Urea for ensuring an adequate ratio $\mathrm{C} / \mathrm{N}$ needed to start the process. This additive is permitted by the legislation on the environment and fertilizers.

\section{Results and discussion}

\section{Characteristics of the rural territory of ARO 1}

The utilized agricultural area (UAA) in the ARO 1 is about 54,990 ha and is being used for the cultivation of: horticultural crops (330 ha) and flower (700 ha) in the open field and greenhouse, cereal (13730 ha), grapes (3760 ha), olive trees (34850 ha) and fruit trees (1620) (Table 3 - Figure 4). The cultivated area is partially characterized by the presence of greenhouse and tunnels (about $338 \mathrm{ha}$ ), plastic film (about 81.0 ha) and plastic nets (about $564.0 \mathrm{ha}$ ) for "tendone systens" used for grapefruit cultivation.

Table 2. Maximum application rate of compost.

\begin{tabular}{lcl}
$\begin{array}{l}\text { Type of cultivation } \\
\text { Arable crops }\end{array}$ & $\begin{array}{c}\text { Maximum application } \\
\text { rate of compost }\end{array}$ & $\begin{array}{c}\text { Unit of } \\
\text { measure }\end{array}$ \\
Horticultural & 7.3 & $\mathrm{t} \mathrm{ha}^{-1} \mathrm{anno}^{-1}$ \\
\hline Fruit trees and vineyards & 14.3 & $\mathrm{t} \mathrm{ha}^{-1} \mathrm{anno}^{-1}$ \\
\hline
\end{tabular}

Table 3. Agricultural use of land.

\begin{tabular}{lcc} 
Type of cultivation & Surface [ha] & $\%$ \\
Horticultural crops & 330 & 0.6 \\
Flower & 700 & 1.3 \\
\hline Arable crops & 13,730 & 24.9 \\
Olive trees & 34,850 & 63.5 \\
\hline Vineyards & 3,760 & 6.8 \\
Fruit trees & 1,620 & 2.9 \\
\hline Total & 54,990 & 10
\end{tabular}


Table 4. Production of agricultural waste in ARO 1.

\begin{tabular}{|c|c|c|c|}
\hline Type of waste & Description of waste & Amount of waste produced & Unità di misura \\
\hline Plastic waste from primary production & $\begin{array}{l}\text { Plastic films for greenhouse covering } \\
\text { Film plastici per la pacciamatura } \\
\text { Plastic films for mulching } \\
\text { Irrigation pipes }\end{array}$ & $\begin{array}{c}523.75 \\
99.0 \\
384.6 \\
22.56\end{array}$ & $\begin{array}{l}\text { t year-1 }^{-1} \\
\text { t year }^{-1} \\
\text { t year }^{-1} \\
\text { t year- }^{-1}\end{array}$ \\
\hline Plastic packaging & Packaging of fertilizers and soil improvers & 110.47 & t year $^{-1}$ \\
\hline Agrochemical waste & Agrochemicals empty containers & 58.03 & t year $^{-1}$ \\
\hline Vegetable waste from primary production & Cuttings and prunings & 72724.0 & t year $^{-1}$ \\
\hline
\end{tabular}

Table 5. Chemical properties of the organic matrices.

\begin{tabular}{lccc} 
Chemical element & Value for olive pruning & Value for horticultural vegetable waste & Unit of measure \\
Nitrogen & 0.45 & 0.49 & $\mathrm{~g} / 100 \mathrm{~g}$ of dry matter \\
Organic carbon & 42.4 & 40.5 & $\mathrm{~g} / 100 \mathrm{~g}$ of dry matter \\
\hline Rate Organic carbon/Nitrogen & 94 & 83 & $\mathrm{~g} / 100 \mathrm{~g}$ of dry matter \\
Phosphorus & 0.04 & $<0.01$ & $\mathrm{~g} / 100 \mathrm{~g}$ of dry matter \\
\hline Potassium & 0.51 & 0.51 & $\mathrm{~g} / 100 \mathrm{~g}$ of dry matter \\
Sodium & 0.188 & 0.063 & $\mathrm{~g} / 100 \mathrm{~g}$ of dry matter \\
\hline Calcium & 1.58 & 1.16 & $\mathrm{~g} / 100 \mathrm{~g}$ of dry matter \\
Magnesium & 0.27 & 0.09 & $\mathrm{~g} / 100 \mathrm{~g}$ of dry matter \\
Iron & 258 & 227 & $\mathrm{~g} / 100 \mathrm{~g}$ of dry matter \\
Copper & 266 & 5 & $\mathrm{~g} / 100 \mathrm{~g}$ of dry matter \\
\hline Zinc & 47 & 17 &
\end{tabular}

\section{Production and management of agricultural waste}

In the rural area of the AR0 no. 1 are produced about 1,030 $\mathrm{t} \mathrm{year}^{-1}$ of plastic waste annually, 73,000 tyear-1 of cuttings and prunings and 58 t year-1 of pesticides used containers. In Table 4 are specified the quantities of each type of waste products estimated through the production coefficients extrapolated from the literature and shown in Table 1.

Plastic wastes, mainly composed of film for covering greenhouses and plastic nets for tendone system, represent the fraction of agricultural waste that creates more environmental and landscape issues. The organization of the collection of this waste for delivery to collection centers may represent a useful solution economically and environmentally.

The collection of plastic waste can have an economic benefit to be distributed among the municipal authority and the service provider for the collection and, to confer this waste to recycling facilities thus avoiding mismanagement of plastic waste by farmers (eg. uncontrolled burning, abandonment, illegal dumping).

A particularly dangerous agricultural waste are used containers of agrochemicals that may have a significant environmental and health risks both. These containers must be disposed of as special waste (Legislative Decree 152/2006) for the serious damage to the environment and persons that substances contained are likely to cause. The collection of these containers from the waste management urban services could allow a correct treatment thus avoiding illegal disposal. Are widespread in northern Europe washing plants for empty containers of agrochemicals which allows to reduce the hazardous properties and to promote recycling as plastic. The washing procedure allows the removal of agrochemicals inside the containers and purification of wastewater deriving from the washing. The wastewater is then treated in bio-filters that are made from organic material called "bio-beds".
Table 6. Amount of MCSI usable in the ARO 1.

\begin{tabular}{lcc} 
Type of cultivation & $\begin{array}{c}\text { Maximum } \\
\text { application of compost }\end{array}$ & $\begin{array}{c}\text { Unit of } \\
\text { measure }\end{array}$ \\
\hline Cereal crops & 100229 & t year $^{-1}$ \\
Horticultural crops & 4719 & t year $^{-1}$ \\
\hline Fruit trees and vineyard & 38198 & t year $^{-1}$ \\
\hline
\end{tabular}

The organic matter present in the bio-bed absorb pollutants and facilitate their biodegradation due to metabolic activity of the microbial component.

The cuttings and prunings are in some cases re-used in farms (green manure, fuel, etc.) and it is therefore necessary to provide for collection in composting plants, only for farms that want this service. An interesting solution for the recycling of organic waste produced in rural areas far from composting plants is represented by the composter community. At community composting plant installed in the greenhouse company "Primavita Srl" were introduced the pruning of olive tree and horticultural and floricultural residues. The organic matrices treated were analyzed for their chemical and physical characterization (Table 5) as well as the product compost. The compost was used to replace in whole or in part the peat used in the substrates. This practice reduces the environmental load because the peat comes from Northern Europe and is being depleted.

\section{Compost usable in ARO 1}

The application of MCSI on agricultural soil of the ARO 1 must not exceed 143,146 t year-1. This amount is allocated to the agricultural areas used for cultivation of different crop types as specified in Table 6 . The application of these quantities can improve the chemical - physical 
and microbiological soil property thus avoiding nitrate leaching and, therefore, without compromising the groundwater quality.

The amount of organic waste required for the production of MCSI is about 429,438 tonnes. In the AR0 1 in the year 2012 were produced $102,263.2$ tons of municipal solid waste (MSW) which are composed by $35 \%$ of organic material (www.rifiutiebonifica.puglia.it). The municipal organic waste produced by domestic users and non-domestic (schools, offices, commercial activities) in the in the ARO 1 are approximately about 108,516 tons and can therefore be entirely destined for composting and be used in local agriculture. To achieve high levels of use in agriculture of GCSI and MCSI are needed adequate awareness and incentives for farmers. The use of MCSI and GCSI is, in fact, a complementary activity to the recycling of organic waste that needs adequate support through Measure 214 "Payment Agro - Environmental" of the Rural Development regarding the adoption of sustainable methods of agricultural production and land management.

\section{Conclusions}

The carried out work provides an appropriate methodology for evaluating the amount of agricultural waste generated and the calculation of the maximum amount MCSI applicable on agricultural soil on a territorial scale.

The evaluation of the maximum utilization rate of MCSI on a territorial scale, and the drafting of appropriate fertilization plans can improve the characteristics of the soil and of agricultural production without damaging the quality of the environmental matrices.

The ability to obtain information on the production of agricultural waste, divided by type, allowing both rapid quantitative estimate, and the correct programming of the collection, transport and disposal/reuse. In this context, the activation of the collection service of plastics waste (plastic films for greenhouses and tendone system, mulching films, agrochemicals empty containers) can increase separate plastic waste collection and their recycling. This collection service may be entrusted to the manager of waste management services or to farmers. The use of GIS can provide valuable support to the organization of the routes and frequencies of collection of agricultural waste as it allows to identify the spatial distribution of production.

The organic vegetable waste, can be transferred and processed in community composters placed in rural areas for the production of GMSI, to be used then for the crops, thus reducing transport for disposal. In order to reduce emissions due to uncontrolled burning or transport, this use permits reuse for agricultural purposes with clear environmental benefits.

The present study thus shows that the rural areas can play an important role in the waste cycle from production to recycling.

\section{References}

ANPA, Agenzia Nazionale per la Protezione dell'Ambiente. 2000. I rifiuti del comparto agricolo.

APAT, Agenzia per la Protezione dell'Ambiente e per i Servizi Tecnici. 2005. Criteri metodologici per l'applicazione dell'analisi assoluta di rischio alle discariche.

ARPA Puglia, Agenzia Regionale per la Protezione Ambientale. 2010. Relazione sullo stato dell'ambiente.

Atrigna M., Canditelli M., Faustini N., Pescheta G. 2011. La gestione della frazione umida/biodegradabile dei rifiuti urbani. Rifiuti
Solidi. 2:101-109.

Baldi E., Toselli M., Marangoni B., Innocenti A., Scudellari D. 2008. Pesco, l'uso del compost migliora la fertilità del suolo. Agricoltura. 1:101-102.

Briassoulis D., Hiskakis M., Babou E., Antiohos S.K., Papadi C. 2012. Experimental investigation of the quality characteristics of agricultural plastic wastes regarding their recycling and energy recovery potential. Waste Management. 32(6):1075-1090.

CADIR-LAB. 1994. Ipotesi di progetto pilota per la raccolta e lo smaltimento di rifiuti agricoli e contenitori esausti di fitofarmaci nell'alessandrino.

Calabrò P.S. 2009. Greenhouse gases emission from municipal waste management: The role of separate collection. Waste Management. 29:2178-2187.

Centeremo M. 2011. Stato dell'arte del compostaggio e digestione anaerobica da rifiuto organici in Italia. Atti della Conferenza nazionale sul compostaggio e la digestione anaerobica, Ecomondo November 2011, Rimini, Italy.

Cotana F., Cavalaglio G. 2008. La valorizzazione energetica delle potature di ulivo. Quaderni Ercole Olivario. 5.

Dal Sasso P., Scarascia Mugnozza G., Marinelli G. 2009. La raccolta di rifiuti plastici in agricoltura: proposta di organizzazione territoriale nelle zone agricole dell'area metropolitana di Bari. Atti del IX Convegno Nazionale dell'Associazione Italiana di Ingegneria Agraria "Ricerca e innovazione nell'ingegneria dei biosistemi agro-territoriali", September 14-16, Ischia, Italy

De Lucia Zeller B., Ingravalle S., Russo G., Scarascia Mugnozza G., Vecchietti L. (2009). Analisi ambientale e agronomica di substrati per piante in vaso da rifiuti organici e agroindustriali. Atti del IX Convegno Nazionale dell'Associazione Italiana di Ingegneria Agraria "Ricerca e innovazione nell'ingegneria dei biosistemi agro-territoriali", September 14-16, Ischia, Italy

Legislative Decree n. 36/2003. Attuazione della direttiva 1999/31/CE relativa alle discariche di rifiuti.

Legislative Decree n. 152/2006. Norme in materia ambientale.

Legislative Decree n. 75/2010. Riordino e revisione della disciplina in materia di fertilizzanti.

Ministerial Decree of 08/04/2008. Disciplina dei centri di raccolta dei rifiuti urbani raccolti in modo differenziato.

Ministerial Decree of 13/05/2009. Modifiche al Decreto Ministeriale del 08/04/2008 sulla disciplina dei centri di raccolta dei rifiuti urbani raccolti in modo differenziato.

European Directive 2008/1/CE. Prevenzione e riduzione integrate dell'inquinamento.

Favoino E., Hogg D. 2002. Biowaste and climate change: a strategic assessment of composting. Gestion des d'echets et changement climatique.

ISPRA, Istituto superiore per la Protezione e la Ricerca Ambientale. 2011. Rapporto sui rifiuti speciali

Picuno P., Scarascia Mugnozza G. 1994. The management of agricultural plastic film wastes in Italy. Proceedings of the International Agricultural Engineering Conference, 6-9 December, Bangkok, Thailandia.

Picuno P., Scarascia Mugnozza G., Sica C. (2009). Proprietà meccaniche e radiometriche di film plastici rigenerati da granulo riciclato di origine agricola. Atti del IX Convegno Nazionale dell'Associazione Italiana di Ingegneria Agraria "Ricerca e innovazione nell'ingegneria dei biosistemi agro-territoriali", September 14-16, Ischia, Italy.

Pivato A., Vanin S., Palmeri L., Barausse A., Mangione G., Rasera M., Monego G. (2012). La Biopotenzialità come indicatore di compensazione ambientale per un impianto di compostaggio. Rifiuti 
Solidi. 1:23-31.

Regione Toscana. 2004. Disciplinare di produzione integrata.

Scarascia Mugnozza G., Vox G., Picuno P. 1999. Metodologie di analisi territoriale in relazione all'uso di plastiche per le coltivazioni protette. Atti del Seminario dell'Associazione Italiana di Ingegneria Agraria "Le colture protette: aspetti agronomici, territoriali e tecnico-costruttivi”, June 24-26, Ragusa, Italy.

Scarascia Mugnozza G., Dal Sasso P. 2007. Film biodegradabili: aumenta il loro impiego nelle colture protette. Colture Protette. 36(8):85-
94.

Scarascia Mugnozza G., Pascuzzi S., Anifantis A., Verdiani G. 2012. Use of low-enthalpy geothermal resources for greenhouse heating: an experimental study. Acta Scientiarum Polonorum. 11:13-19.

www.rifiutiebonifica.puglia.it

Zorzi G., Silvestri S., Cristoforetti A. 2010. Il compostaggio e il suo ruolo strategico in un sistema integrato di gestione dei rifiuti. Rifiuti Solidi. 2:105-117. 